\title{
Confucianism Ethic and the Spirit of Capitalism'
}

\author{
Usman \\ Research Center for Society and Culture \\ email:asyqi_wahidi@yahoo.com
}

\begin{abstract}
This article tries to explore the fundamental values of Confucianism ethics and its influence to the emergence of Capitalism. By using Weber's thesis on the relationship between Protestant ethics and the spirit of capitalism, this paper concludes that the three important values of Confucianism Ethics (ren: benevolence, humaneness, li: rightness, righteousness, and fittingness, and yi: rules of proper conduct, ritual, and rites) are proposing people on how to become good human beings. If the Confucian follows these ethics properly, he/she will get the successful life. Although it is not guaranteed but the Confucianism ethics are still relevant to be practiced in contemporary situation. Some research findings recently showed that Confucianism ethics have really influence people to fulfill the "calling" (Weber's term) and it has also power to increase the spirit of capitalism. The rise of Japan, China, and the four little dragons (including South Korea, Taiwan, Hong Kong, and Singapore) is related to the development of Confucianism, and it directly brings down Weber's view point, which taught that Confucianism did not have the spirit of capitalism.
\end{abstract}

\section{Keywords}

Confucianism Ethics, Confucian, Capitalism

\section{Introduction}

Historically, according to Weber, Confucianism did not encourage capitalistic innovations among businessmen in China because they often

1 This title has inspired by Weber's work on The Protestant Ethic and the Spirit of Capitalism. 
emphasize to practice the rituals to their ancestors, emphasizing on the traditions, the reliance on moral cultivation of the scholar-bureaucrat (as opposed to the profit-making activities of the merchants), and the maintenance of hierarchical relationship (Tamney and Chiang 2002, 63-64). At a glance, it seems that there are contradictions between the Confucianism ethics and the spirit of capitalism, but actually in the recent studies of contemporary Confucianism, some scholars and Confucians rejected it. For instance, Gery Kok Yew Chan who have stated that the economic success of the East Asian economies (such as Japan, South Korea, Taiwan, and Hong Kong) have been attributed to Confucianism by various scholars and politicians (Chan 2008, 348).

Another scholar, James B. Palais, asserted in his writing about Confucianism and Economic Development in South Korea that Confucianism has played an important role for the successful economic development (Palais 2002, 507). He believed that incentives, such as economic success, government income, rising income, and popular approval outweighed responsibility to the family, which they assumed was the greatest indicator of the sense of Confucian ethic obligations. Besides, the Confucian ethics are really having strong encouragement for the local identity and initiative, as the central state clears away obstacles to individual and family strategies for educational, entrepreneurial, and knowledge-based success. From the various scholars' ideas that mentioned above, this paper taking position that Confucianism ethics are able to influence people to fulfill the "calling" (Weber's term), and it has also the power to increase the spirit of capitalism, because Confucianism has really care to support human being in order to get successful life in this world.

This article will be focused on discussing about the Confucianism ethics and the spirit of capitalism. There are two main questions related to these issues. Firstly, what Confucianism ethics are? Secondly, how the Confucianism ethics are influencing to the emergence of Capitalism. 
Weber's theory will be used to analyze these questions. Weber's thesis proposes a relationship between the spirit of capitalism and the Protestant ethic. Weber tried to trace the connection between ethico-religious values on one hand, and the structures which motivate various kinds of economic development on the other hand. Briefly, according to Weber, the religious consciousness determines social consciousness.

\section{Confucianism Ethics}

The core of Confucianism ethics is constituted of three elements - ren (benevolence, humaneness), li (rightness, righteousness, and fittingness), and $y i$ (rules of proper conduct, ritual, and rites) that define what is morally acceptable in human society (Ip 2009, 464). The first, ren which is in the broad sense understood as a Confucius's Dao vision of the good, an ideal theme as concern for humanity. Fundamentally, ren is the love of fellow human or affectionate concern for the well-being of humanity (Shen and Shun 2008, 12). From this, we can say that the main concern of Confucianism is how we learn to be human. It soundly just a simple things, but practically is not as easy as said, because Confucian thought takes humanistic orientation and advocates a humanistic way of life. Of course, definitively all of us surely as human being, but we must still consciously learn to be human (Wei-Ming 1984, 4).

Within the learning process to be human there are things to be involved, at least self-cultivation, self-mastery, and self-understanding. So, what "self" carries out to this endeavor? Within Confucian tradition, "self" are clearly differentiated into two categories, i.e. the small self and the great self. The small self is the limited self. It operates as a force of inertia that resists further development. It is neither dynamic nor transformative. Meanwhile the great self goes beyond the self-centeredness. It relates to the family, to the society, to the state, and beyond to the world at large (Wei-Ming 1984, 8). Therefore, the commitment to ren involves 
benevolence is desire to be good to others, as well as to "learn the good of others." In addition, to cultivate oneself into an ideal person with the moral experience into the ultimate and transcendental realm, one has to open up a channel from internal to external through which the ideal form can be realized into the social practice. Contemporary Confucians think that their ideal functions have not only to sustain individual well-being, in terms of morality, but also to provide good moral order for the society (Richey 2008, 177).

The second ethic teaching of Confucianism is $l i$. It is usually translated as ritual in English, even it is inadequate translation. Li began as a term for sacrifices to ancestors and to deities. Its meaning later expended to the institutionalized and stylized behavior of nobility, ranging from political institutions such as the "feudal system to ceremonies and life-cycle rites to standards of decorum and social manners. Thus, $l i$ has come to the all patterns of behavior (Chow 1994, 9). The third ethic teaching is $y i$. It is a corpus of proper conduct. It is the sense of rightness, righteousness, and fittingness that would be the basis of modification of $l i$. So, the concern of $y i$ is generally concerning to the right action, which is deemed fitting or appropriate to particular situation (Chow 1994, 21).

In the Confucian tradition, such as struggle is manifested into the dialogue on the relationship between yi (rightness, righteousness, and fittingness) and $l i$ (rules of proper conduct, ritual, and rites). Confucius said: "The gentlemen can be reasoned with what is moral. The common man can be reasoned with what is profitable". It seems that Confucianism gives more attention to the moral conditions rather than to the outer world. It is not totally correct, considering that this issue still becomes debatable issue among some scholars. In other word, the struggle between the pursuit of material interest and adherence to moral values is a perennial problem of human existence, and to put moral perception into the practical constitutes to the central issues in capitalism spirit (Cheung \& King 2004, 245). 
Mencius explains that the way of being human is in the term of basic ethics qualities, as he mentioned below:

"A man without feeling of commiseration is not human. A man without a feeling of shame and dislike is not human. A man without a feeling of difference and compliance is not human. A man without a feeling of right and wrong is not human. The feeling of commiseration is the germination of humanity. The feeling of shame and dislike is the germination of righteousness. The feeling of difference and compliance is the germination of propriety. And the feeling of right and wrong is the germination of wisdom. Men have these four germinations just as they have their four limbs, but saying that they cannot develop themselves, is self-destruction... If anyone with these four germinations in him knew how to give them the fullest extension and development, the result would be like fire beginning to burn or spring beginning to shoot forth.” (2A: 6).

Thus, based on the explanation above can be identified that the ethics of the Confucian heritage supportive of growth are: competitive dedication to improve the relative position of self and family; respect for education as a vehicle for self-improvement; inculcation of qualities of hard work, diligent, and self-discipline; absence of religious or ideological constraints inhibiting the pragmatic pursuit of ends; and ability to subordinate self and participate effectively in a hierarchical structure yielding a synergistic effect on output (Palais 2002, 508).

\section{The Spirit of Capitalism}

Before discussing the spirit of Capitalism and its relation to the Confucianism, it would be better to know the number of Confucians on the World. There are about 6 million people who were acknowledged themselves as Confucians. The majority of them were living in Asia, more particularly East Asia, considering to the birthplace of Confucianism was in China. Even though there were also the Confucians who were 
living in Europe, North and South America, and some other countries or continents even in the small numbers (Dorothy and Hoobler 2009, 9). It means that when they are identifying themselves as Confucians, meaning that they still following the Confucianism ethics.

In his study on Confucianism, Taoism and economic ethics, Weber cited 169 titles by ninety-six authors. He defined Confucianism as the class ethics of prebendaries or office-holders who were educated in wordlyrationalistic things. The ethics have influenced Chinese life, manners, and letters in general. Considering Confucians as equivalent to prebendaries indicates that, for Weber, the Chinese literati were a kind of pastors who's only having aim in life was to grab the endowments that came with their offices (Hsia 2004, 106).

According to Weber, Confucianism has produced theories of supply and demand, speculation and profit, which is soundly very modern. In contrast to the Occident of the profitability of money went without saying, and theory apparently knew no barriers to interest. Interest, in Chinese as in Greek, is called the "infant" of capital. Certain imperial statutes, to be sure, rejected certain kinds of "usury." But the capitalist, as privately interested man, was not to become an official and the educated literati were to stay away from chrematistics. Wherein the social doubts about the profit motive per se emerged, they were essentially political in nature (Weber 1951, 159). It can be seen starting from the middle of the Ming Dynasty, probably due to a large movement of Confucian scholars into trade of business, there was a fusion of the horizon of the world of scholars and the conception of the relationship between righteousness and profitableness had never become the mainstream of social values in the late of Chinese imperial (Cheung \& King 2004, 146).

Thus, Confucianism was naturally and predominantly oriented toward a consumers' policy. Still hostility toward economic profit was quite remote, as it was also in the popular mind (Weber 1951, 158). In 
this way, it seems that Weber tends to criticize Confucianism. In fact, many people believe that following Confucianism does not mean that we are not allowed to become wealthy, but some others also argued that we cannot follow Confucius by buying into the values of the modern world, particularly its obsession with money (Rainey 2010, 196).

Weber insisted that Confucianism lacked the necessary of tensionwhich is emphasized to the quality, harmony, decency, virtue, and pacifism—so that was impossible for China to develop capitalism (Hsia 2004, 108). In the conclusion, we can see some critical thought of Weber on Confucianism in particular, and on Chinese religion in general. Weber summarized why capitalism has never develop in China. The first mistake, it was considered that the world was the best of all possible worlds; thereby it is lacked to the notion of a world after death. The second mistake, human beings were supposed to be innately good and perfectible. The third mistake is the belief that the "right path of salvation" was adapting oneself to Tao, the cosmic harmony. The fourth, shortcoming was a belief in ideal of grace and dignity which have a connection with beauty and morals. The fifth mistake, is considering decency and propriety as the central virtues (Weber 1951, 226-249).

Similar to Weber's arguments, Tu Wei-Ming schematized his arguments into three propositions. The first proposition is that the modern person confronted to a host of competing spheres of interest. The second proposition involves an idea of the notion of "calling" or vocation. It is interesting to take attention on Tu Wei-Ming's interpretation of "calling." He underlined that 'calling' is not just limited to the religious calling, but has broader meaning; such as Science calling, Political calling, and success calling in business world. Consequently, the modern person holds normative beliefs on such calling requires. Since, everyone has purpose to be the best. The third proposition is that the religious values have linkage to the first and the second proposition (Wei-Ming 1984, 75-76). 
Although Wei-Ming basically agreed to Weber's thesis, but at the end of his argument he came up with the different conclusion. He asserted that historians, sociologists, political scientists, and academicians especially those who are taking concern to the comparative religions issues have identified some of the communal values or Confucianism ethics-to be exact, has contributed to the rise of a new kind of capitalism. Finally, he agreed to Peter Berger's terminology to call Confucianism as a "modern capitalism," or "second wave of modernity." He has then identified five regions, in which the Confucian ethic seems to feature prominently: Japan, South Korea, Taiwan, Hong Kong, and Singapore. In some cases, he said that some of the economic developments in Japan have been attributed to the Confucianism ethics (Wei-Ming 1984, 84).

In regard to the problem of social practice, contemporary Confucians take up the discourse of the new Weberian thesis addressed by sociologists such as Peter Berger and Ambrose King. According to these sociologists' view, Max Weber is wrong in saying that there is no functional equivalent to the Protestant ethic in the non-Western world that can give rise to modern capitalism. They think that the successful economic phenomena that occurred in Japan and the four little dragons (including South Korea, Taiwan, Hong Kong, and Singapore) after World War II are considered as counter examples of Weber's viewpoint. However, on the other hand, they think that Weber is right in saying that religious (and moral) values are relevant to the rise of modern economic growth. They claim that institutional factors are not crucial to explaining these East Asia phenomena; Confucian values (as described by Berger as "vulgar Confucianism" or by King as "instrumental Confucianism") are common to all of these communities, and can be considered as cultural factors to explain the phenomena with good statistic evidences. To extent this new Weberian thesis, some scholars claim that the Confucian values can be a positive constituent of modernization. They assert that these 
values playing a significant role, not only in economic growth but also in the social and political construction (Richey 2008, 177).

In this situation, would be better for us to comparing analysis between Weber's thesis and the Weberian thesis. Weber's thesis on the Protestant ethic can be as a unique factor for the emergence of capitalism, and the other non-Western civilizations do not have this factor. While the Weberian thesis attacks the aspect of the uniqueness of Weber's thesis on the one hand, and maintains some sort of the instrumental Confucianism that can be considered as a functional equivalent to the Protestant ethic in promoting Capitalism in East Asia on other. Werner Sombart has disagreed to Weber's thesis. He provides the different ideal type of capitalism and considers that the Protestant ethic as epiphenomenal to human interest and its behavioral performance as supervenient (or dependent) on economic behavior. Although Sombart also gives an idealistic explanation to the rise of Capitalism, he stresses on the human interest more than Protestant ethics. He thinks that the capitalist spirit was combination of the spirit of enterprise, which was associated with acquisitiveness and competition, and the bourgeois spirit, which was epitomized by methods of exact rational calculation, careful business planning, and efficiency. For Sombar, people with the Protestant ethics, but Jews who embodied all the traits valued most highly by market -egoism, self-interest, and abstract thinking (Richey 2008, 179).

\section{Conclusion}

To sum up, this article come up to the conclusion that Confucianism ethics contain three important values, namely: ren (benevolence, humaneness), $l i$ (rightness, righteousness, and fittingness), and $y i$ (rules of proper conduct, ritual, and rites). The main core for Confucianism ethics is to teach people how to become human beings. If Confucian follows these ethics properly, he will get the successful. Although it is not 
guaranteed but the Confucianism ethics are still relevant to be practiced in contemporary situation. Some scholars stated that the rise of Japan, China and the four little dragons (including South Korea, Taiwan, Hong Kong, and Singapore) is related to the development of Confucianism, and it directly brings down Weber's viewpoint, which taught that Confucianism did not have the spirit of capitalism.

\section{References}

Chan, Gery Kok Yes. 2008. The Relevance and Value of Confucianism in Contemporary Business Ethics. Journal of Business Ethics, Vol. 77 No. 3, 347-360.

Cheung, Tak Sing \& King, Ambrose Yeo-Chi. 2004. Righteousness and Profitableness: The Moral Choices of Contemporary Confucian Entrepreneurs. Journal of Business Ethics, Netherlands: Kluwer Academic Publishers, 245-260.

Chow, Kai-wing. 1994. The Rise of Confucian Ritualism in Late Imperial China, Ethics, Classics, and Lineage Discourse. The United States of America: Stanford University Press.

Dorothy and Thomas Hoobler. 2009. World Religions: Confucianism. New York: An Imprint of InfoBase Publishing.

Hsia, Adrian. 2004. Richard Wilhelm's Reception of Confucianism in Comparison with James Legge's and Max Weber's. Journal of Ecumenical Studies, United States of America: Ecumenical Press, 96-119.

Ip, Po Keung. 2009. Is Confucianism Good for Business Ethics in China?. Journal of Business Ethics, Vol. 88. No. 3, 463-476.

Levenson, Joseph R. 1965. Confucian China and Its Modern Fate: A Trilogy. California: University of California Press.

Palais, James B. 2002. "Confucianism and Economic Development in South Korea', In Benjamin A. Elman (et. all), Retbinking Confucianism Past and Present in China, Japan, Korea, and Vietnam. Los Angeles: UCLA Asian Pasific Monograph Series.

Rainey, Lee Dian. 2010. Confucius and Confucianism, the Essentials. United Kingdom: Wiley_Blackwell, a Jhon Wiley \& Sons, Ltd. Publication. 
Richey, Jeffrey L. (ed.). 2008. Teaching Confucianism. New York: Oxford University Press.

Rozman, Gilbert, 2003. "Center-Local Relation: Can Confucianism Boost Decentralization and Regionalism," in Daniel A. Bell and Hahm Chaibong, Confucianism for the Modern World. New York: Cambridge University Press.

Shen, Vincent and Kwong-lo Shun (eds.). 2008. Confucian Ethics in Retrospect and Prospects, Chinese Philosophical Studies XXVII. Washington D.C.: The Council for Research in Values and Philosophy.

Tamney, J.B. and L.H.L Chiang, 2002. Modernization, Globalization, and Confucianism in Chinese Societies. Westport, Connecticut : Praeger Publishers.

Weber, Max. 1958. The Protestant Ethic and the Spirit of Capitalism. New York: Charles Scribner's. .1951. "The Religion of China, Confucianism and Taoism", translated and edited by Hans H. Gerth. Illionis: The Free Press, Glencoe.

Wei-Ming, Tu. 1984. Confucian Ethics Today, the Singapore Challenge. Singapore: Federal Publication. 